\title{
Multiple Resistance of Sagittaria montevidensis BIOTYPES TO Acetolactate Synthase and Photosystem II Inhibiting HERBICIDES ${ }^{1}$
}

\author{
Resistência Múltipla de Biótipos de Sagittaria montevidensis aos Herbicidas Inibidores da \\ Acetolactato Sintase e Fotossistema II
}

MOURA, D.S. ${ }^{2}$, NOLDIN, J.A. ${ }^{3}$, GALON, L. ${ }^{4}$, SCHREIBER, F. ${ }^{2}$, and BASTIANI, M.O. ${ }^{2}$

\begin{abstract}
The objective of this research was to evaluate the occurance of multiple resistance of Sagittaria montevidensis (SAGMO) biotypes to acetolactate synthase (ALS) and photosystem II (PSII) inhibiting herbicides through dose-response experiments. The experiment was conducted in a greenhouse from October 2012 to March 2013, in Pelotas, RS. The experimental design was completely randomized, with four replications. Treatments were arranged in a triple factorial design: two biotypes of $S$. montevidensis (SAGMO 35 - susceptible to herbicides and SAGMO 32 - suspected to be multiple resistance to ALS and PSII inhibiting herbicides), four herbicides (penoxsulam, (imazethapyr+imazapic), bentazon and saflufenacil) and 8 rates of these herbicides $(1 / 32 \mathrm{x}, 1 / 16 \mathrm{x}, 1 / 8 \mathrm{x}, 1 / 4 \mathrm{x}, 1 / 2 \mathrm{x}, 0 \mathrm{x}, 1 \mathrm{x}, 2 \mathrm{x}, 4 \mathrm{x}, 8 \mathrm{x}, 16 \mathrm{x}, 32 \mathrm{x}$ and $64 \mathrm{x})$. SAGMO 32 biotype presented high levels of resistance to penoxsulam, (imazethapyr+imazapic) and bentazon. For a 50\% reduction in dry matter of the resistant biotype rate of 138 and 2.46 times higher than the label required for the susceptible biotype of the herbicides (imazethapyr+imazapic) and bentazon, respectively, are required. Saflufenacil may be used successfully to control Sagittaria montevidensis resistant in irrigated rice.
\end{abstract}

Keywords: California arrowhead, Oryza sativa, water-seeded rice, herbicide resistance, chemical control, Ricer ${ }^{\circledR}$, Only®, Basagran ${ }^{\circledR}$, Heat ${ }^{\circledR}$.

RESUMO - O trabalho teve por objetivo confirmar a ocorrência de resistência múltipla de biótipos de sagitária (Sagittaria montevidensis - SAGMO) a herbicidas inibidores da acetolactato sintase (ALS) e do fotossistema II (FSII), por meio de curvas de dose-resposta. O experimento foi realizado em casa de vegetação no periodo de outubro de 2012 a março de 2013, em Pelotas, RS, através do delineamento experimental inteiramente casualizado com quatro repetições. Os tratamentos foram arranjados em esquema fatorial triplo: dois biótipos de SAGMO (SAGMO 35 - suscetivel e SAGMO 32 - com suspeita de resistência múltipla a herbicidas inibidores da acetolactato sintase - ALS e do fotossistema II - FSII), quatro herbicidas (penoxsulam, (imazethapyr+imazapic), bentazon $e$ saflufenacil) e doses dos mesmos herbicidas, sendo oito doses para o SAGMO 35 (1/32x, 1/16x, $1 / 8 x, 1 / 4 x, 1 / 2 x, 0 x, 1 x$ e 2x) e oito para o biótipo SAGMO 35 (0x, 1x, 2x, 4x, 8x, 16x, 32x e 64x), sendo x igual à dose registrada para o controle dessa planta daninha. O biótipo SAGMO 32 apresentou valores elevados de fator de resistência para penoxsulam, (imazethapyr+imazapic) e bentazon. Para redução de 50\% da massa seca da parte área do biótipo resistente, são necessárias doses 138 e 2,46 vezes maiores do que as exigidas para o biótipo suscetivel, dos herbicidas (imazethapyr+imazapic) e bentazon, respectivamente. O saflufenacil pode ser utilizado para controle de populações de SAGMO com resistência múltipla aos herbicidas inibidores da ALS e FSII na cultura do arroz irrigado.

Palavras-chave: Sagitaria, Oryza sativa, sistema pré-germinado, resistência a herbicidas, controle químico, Ricer ${ }^{\circledR}$, Only ${ }^{\circledR}$, Basagran ${ }^{\circledR}$, Heat ${ }^{\circledR}$.

1 Recebido para publicação em 27.4.2015 e aprovado em 30.7.2015.

2 Universidade Federal de Pelotas, Pelotas-RS, Brasil, <diogodasilvamoura@yahoo.com.br>; ${ }^{3}$ Epagri - Empresa de Pesquisa Agropecuária e Extensão Rural de Santa Catarina, Itajaí, SC, Brasil; ${ }^{4}$ Universidade Federal da Fronteira Sul, Erechim, RS, Brasil. 


\section{INTRODUCTION}

Sagittaria montevidensis. (common names include giant arrowhead and California arrowhead) has been considered one of the main weeds in the rice-growing areas in Santa Catarina (SC) and Rio Grande do Sul (RS), southern Brazil, mainly under the water-seeded system (Cassol et al., 2008). Typically from flooded environments, this species is mainly established in areas with low planting density, competing with rice for water, light and nutrients, reducing crop yield and devaluing the final product (Concenço et al., 2007). The level of damage caused by $S$. montevidensis in irrigated rice crops is variable and can be associated with the soil preparation, cultivars, soil fertility, planting timing, and rows spacing, within others.

Among the control methods for SAGMO, farmers have used the chemical one, with herbicide applications. However, the use of herbicides at non-recommended rates and/or the absence of mechanisms of action rotation have resulted in selection of resistant populations (Shrestha et al., 2010; Powles \& $\mathrm{Yu}, 2010)$. Herbicide resistance is defined as the natural and inheritable ability of certain biotypes within a population to survive and reproduce after exposure to herbicide rates that would be lethal to susceptible individuals of the same species (Christofoletti, 2001; Powles \& Yu, 2010). Importantly, rice crop infested with California arrowhead resistant to ALS and PSII inhibiting herbicides are frequent due to the extensive and repetitive application of herbicides with these mechanisms of action for weed control in irrigated rice. Studies conducted in Santa Catarina have showed the occurrence of a California arrowhead biotype with multiple resistance to ALS and PSII inhibiting herbicides where, under controlled conditions, herbicides penoxsulam, pyrazosulfuron-ethyl, (imazethapyr+imazapic), and bentazon, applied at $8 \mathrm{x}$ the label rate showed control of only $17,4,29$ and $49 \%$, respectively, evidencing the population's high degree of resistance (Eberhardt \& Noldin, 2011; Eberhardt et al., 2013).

Various S. montevidensis biotypes have been identified resistant to ALS inhibiting herbicides (Merotto Jr. et al., 2010). The occurrence of SAGMO populations resistant to PSII inhibiting herbicides was later found in Santa Catarina, which initially emerged as an alternative to control ALS tocontrol ALS resistant biotypes (Eberhardt \& Noldin, 2011). Currently, S. montevidensis biotypes have shown multiple resistance, i.e., they are resistant to ALS and PSII inhibiting herbicides (Eberhardt \& Noldin, 2011; Eberhardt et al., 2013). Thus, the control of S. montevidensis in irrigated rice fields has become more difficult, since ALS and PSII inhibiting herbicides are the most commonly used for weed management in rice.

The aim of this study was to confirm the occurrence of multiple resistance of $S$. montevidensis biotypes to acetolactate synthase and photosystem II inhibiting herbicides.

\section{MATERIAL AND METHODS}

The study was conducted from October 2012 until March 2013, in a greenhouse at Federal University of Pelotas, RS. The experimental design was completely randomized block with four replications, arranged as a factorial (2 $\mathrm{x} 4 \times 8)$.

Factor A consisted of two SAGMO biotypes: SAGMO 35, susceptible to herbicides; and SAGMO 32, suspected to be multiple resistance to ALS and PSII inhibiting herbicides, collected in the counties of Bombinhas and Ilhota, respectively, both in the state of Santa Catarina.

Factor B consisted of four herbicides labeled for weed control in irrigated rice, and factor $\mathrm{C}$ consisted of herbicide rates in order to determine $\mathrm{C}_{50}$ values (rate required to get $50 \%$ control) and $\mathrm{DM}_{50}$ (herbicide rate which results in $50 \%$ reduction of dry matter).

Herbicides evaluated at their labeled rates were: Ricer (penoxsulam at $60 \mathrm{~g}$ a.i. ha ${ }^{-1}$ ) + Veget'Oil ${ }^{\circledR}-1 \mathrm{~L} \mathrm{ha}^{-1}$ ); Only (imazethapyr+ imazapic) at $\left(75+25 \mathrm{~g}\right.$ a.i. ha $\left.{ }^{-1}\right)+$ Dash $\mathrm{HC}^{\circledR}-$ $0.5 \% \mathrm{v} / \mathrm{v}$ ); Basagran (bentazon at $960 \mathrm{~g}$ a.i. ha ${ }^{-1}$ ) + Assist $^{\circledR}-1 \mathrm{~L} \mathrm{ha}^{-1}$ ); and Heat (saflufenacil at 100 g a.i. ha-1)+Dash $\mathrm{HC}^{\circledR}-0.5 \% \mathrm{v} / \mathrm{v}$ ). Herbicide rates were: $0 \mathrm{x}, 2 \mathrm{x}, 1 \mathrm{x}, 1 / 2 \mathrm{x}, 1 / 4 \mathrm{x}$, $1 / 8 \mathrm{x}, 1 / 16 \mathrm{x}$ and $1 / 32 \mathrm{x}$ for the susceptible 
biotype and $0 \mathrm{x}, 1 \mathrm{x}, 2 \mathrm{x}, 4 \mathrm{x}, 8 \mathrm{x}, 16 \mathrm{x}, 32 \mathrm{x}$ and $64 \mathrm{x}$ for the resistant biotype, with ' $x$ ' being equivalent to the herbicide label rate.

The experimental units consisted of plastic pots filled with $4 \mathrm{~kg}$ of soil. The soil used did not present a history of herbicide application in the past five years, being from horizon A of area cultivated with irrigated rice, classified as Solodic Eutrophic Haplic Planosol, belonging to Pelotas Mapping Unit (Embrapa, 2006). In each experimental unit, about 40 seeds of one of the SAGMO biotypes were sown. Immediately after sowing, the seeds were submerged by $5 \mathrm{~cm}$ depth of water, which was kept constant throughout the experiment, enabling the proper development of SAGMO plants and suppression of germination of other weeds. Fertilization was done at the sowing time, according to the recommendations for irrigated rice in southern Brazil (SOSBAI, 2014).

Prior to the moment of herbicides application, SAGMO plants thinning was conducted, remaining six seedlings per experimental unit. The herbicides were applied when SAGMO plants were 5 to $10 \mathrm{~cm}$ high, only with lanceolate leaves, using a backpack sprayer pressurized with $\mathrm{CO}_{2}$, equipped with an XR 110.015 fan-type spray nozzle, regulated with a $210 \mathrm{kPa}$ pressure, and calibrated to apply a spray volume of $150 \mathrm{~L} \mathrm{ha}^{-1}$.

The control of SAGMO plants was evaluated at 14 and 28 days after treatments (DAT), assigning scores from 0 to $100 \%$, considering zero to no control and 100\% to plants death (SBCPD, 1995). At 28 DAT, SAGMO shoots dry matter (DM) was determined. For this, plants were cut at the ground level and stored in paper bags. Subsequently, they were dried in a forced air circulation oven at $60{ }^{\circ} \mathrm{C}$ until constant weight. The plants DM values found were corrected for percentage values, comparing the data obtained in the treatments with herbicide with the control

The data were tested for normality by the Shapiro-Wilk test, and homoscedasticity by the Hartley's test, and subsequently subjected to analysis of variance ( $p \leq 0.05)$. If it was found statistically significant, there was a regression analysis, and comparison was held among the $\mathrm{C}_{50}$ or $\mathrm{DM}_{50}$ values for the biotypes, by means of confidence intervals at $95 \%$ of parameter error probability.

Regression analysis was performed by adjusting the data to the logistic-type sigmoidal regression equation proposed by Streibig (1988):

$$
Y=\frac{a}{\left[1+\left(\frac{x}{x_{0}}\right)^{b}\right]}
$$

where: $Y=$ percentage of control; $x=$ herbicide dose; $a, x_{0}$ and $b=$ equation parameters, being $a$ the difference between the maximum and minimum points of the curve, $\mathrm{x}_{0}$ being the dose providing $50 \%$ of response variable and $b$ the slope of the curve.

From the $\mathrm{C}_{50}$ and $\mathrm{DM}_{50}$ values were obtained resistance factors (RF) for the $S A G M O$. For using RF was necessary to verify the confidence interval $(p \geq 0.95)$ of the susceptible biotype compared to the resistant one. The susceptible biotype confidence interval overlap, compared to the resistant one, indicates that there is no significant difference between $\mathrm{C}_{50}$ and $\mathrm{DM}_{50}$ of the biotypes.

\section{RESULTS AND DISCUSSION}

The data met the analysis of variance assumptions, and there was an interaction ( $\mathrm{p} \leq 0.05$ ) for SAGMO control at 14 DAT for the factors biotypes $\mathrm{x}$ herbicides and biotypes rates, and at 28 DAT among all the factors studied. There was no interaction between biotypes $\mathrm{x}$ herbicides and biotypes $\mathrm{x}$ rates. However, to comprise the objective of the study, only the results of control and dry matter due to the rates for each herbicide are presented.

Considering the susceptible biotype and the variable control at 14 and 28 DAT, the data were satisfactorily adjusted to the logistictype sigmoidal regression equation for herbicides (imazethapyr+imazapic), bentazon and saflufenacil (Figure 1). There was no adjustment of the data to the model for the herbicide penoxsulam because the lower rates used in the experiment $(0.03 \mathrm{x}$ and $1 \mathrm{x})$ provided around 90\% control of SAGMO. Prigol et al. (2014) reported that Euphorbia biotypes 
suspected to be resistant to PROTOX and ALS inhibiting herbicides also did no showed data adjustments to the model used in implementing cloransulam-methyl on the weed assessed agreeing with the results of this study.

For the control of the resistant biotype, at 14 and 28 DAT, there was an adjustment to the logistic-type sigmoidal regression equation for bentazon (Figure 1). However, for herbicides penoxsulam and (imazethapyr+imazapic) there was no adjustment of the data to the model, because the levels of control for all rates used remained between 10 and 50\%.

According to the logistic models parameters adjusted to the SAGMO control levels it was possible to calculate the values of $\mathrm{C}_{50}$ (Christofoletti, 2002), which is the rate required to control $50 \%$ of the population, and consequently the resistance factor (RF). Thus, for the variable control at 14 DAT, herbicides (imazethapyr+imazapic), bentazon and saflufenacil required $0.13,0.40$ and 0.18 times the recommended rate to control $50 \%$ of the susceptible population (SAGMO 35), respectively. The population of SAGMO 32, required 2.90 times the recommended rate of bentazon to get the same level of control. The SAGMO control data at 28 DAT show that herbicides (imazethapyr+imazapic), bentazon and saflufenacil required 0.25, 1.62 and 1.13 times the recommended rate for controling $50 \%$ of SAGMO 35, respectively (Table 1). However, SAGMO 32 biotype required 8.57 times the recommended rate of bentazon to achieve the same level of control.

Considering the variable control at 14 and 28 DAT and the lack of confidence interval (CI) overlap of the susceptible biotype with the resistant one, it was possible to establish the RF value for herbicide bentazon: 7.25 and 5.29 , respectively (Table 1 ). That is, to provide biotype equivalent control, it is necessary for the biotype resistant at 14 DAT, a seven times higher rate than that required for the susceptible biotype, and at 28 DAT, a five times higher dose. It was not possible to calculate the RF for herbicides penoxsulam and (imazethapyr+imazapic), since none of the biotypes, susceptible (SAGMO 35) or resistant (SAGMO 32) reached $50 \%$ control with the tested rates (Figure 1). The multiple resistant biotype (SAGMO 32) did not show resistance to saflufenacil.

There was a decrease in the amount of DM for the two biotypes as the increase in the herbicides rates, except for penoxsulam, (Figure 2). For both biotypes, the variable DM satisfactorily adjusted the logistic-type sigmoidal regression equation to herbicides (imazethapyr+imazapic), bentazon and saflufenacil (Figure 2). There was no adjustment of the data to the model for both biotypes for the herbicide penoxsulam because even the low rates used caused a reduction in dry matter accumulation in the susceptible biotype and virtually no effect on the resistant one.

The herbicides (imazethapyr+imazapic), bentazon and saflufenacil required $0.10,1.25$ and 0.38 times the recommended rate to decrease DM in 50\% for the susceptible biotype SAGMO 35, respectively. The resistant biotype SAGMO 32 required 13.80, 3.08 and 0.56 times the recommended rate to reduce $50 \%$ for the same herbicides (Table 2).

The RF based on the variable DM for herbicides (imazethapyr+imazapic) and bentazon, was of 138 and 2.46, respectively (Table 2). The high RF value for (imazethapyr+ imazapic) occurred due to the high efficiency of this herbicide on the susceptible biotype, since approximately $10 \%$ of the recommended rate was sufficient to inhibit the DM accumulation. However, it is noteworthy that even using 64 times the recommended rate, this was not enough to completely inhibit the development of the resistant biotype. The low value of RF for bentazon was due to the herbicide rate effectiveness similarity of susceptible and resistant biotypes. For saflufenacil, even if the biotypes have not shown resistance to this herbicide, it was possible to calculate the RF, which was 1.47 .

Overall, for SAGMO 32 biotype, resistant to ALS and PSII, boosting penoxsulam and (imazethapyr+imazapic) rates did not changed the level of control and DM. The highest level of control shown for biotype SAGMO 32 was approximately $30 \%$ at 14 DAT, with a penoxsulam rate 64 times the recommended one. The low level of control observed for ALS 
14 DAT
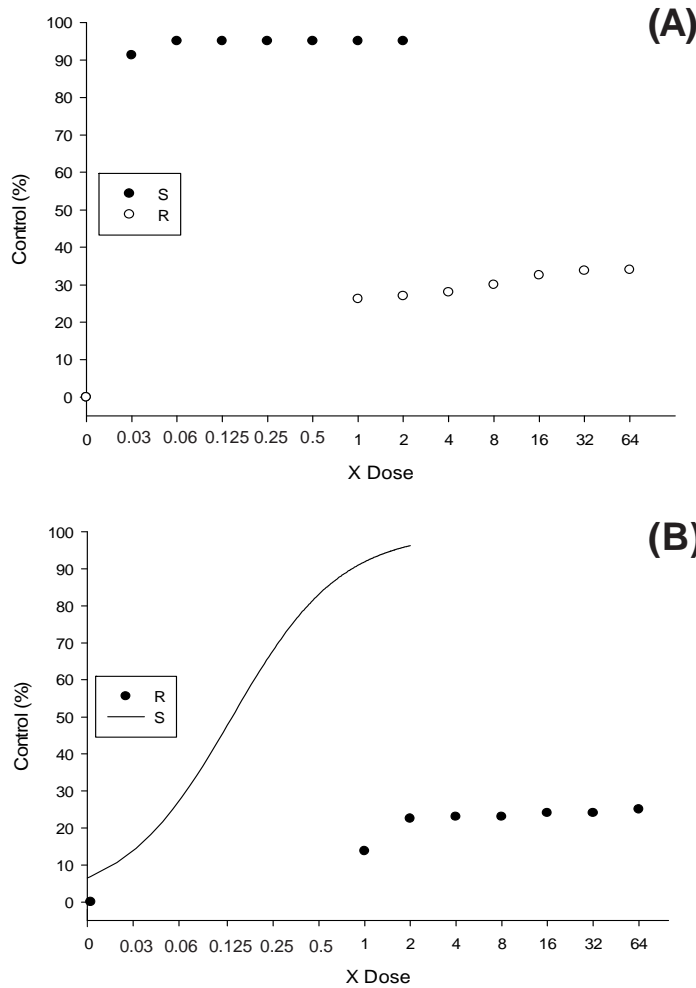

(C)
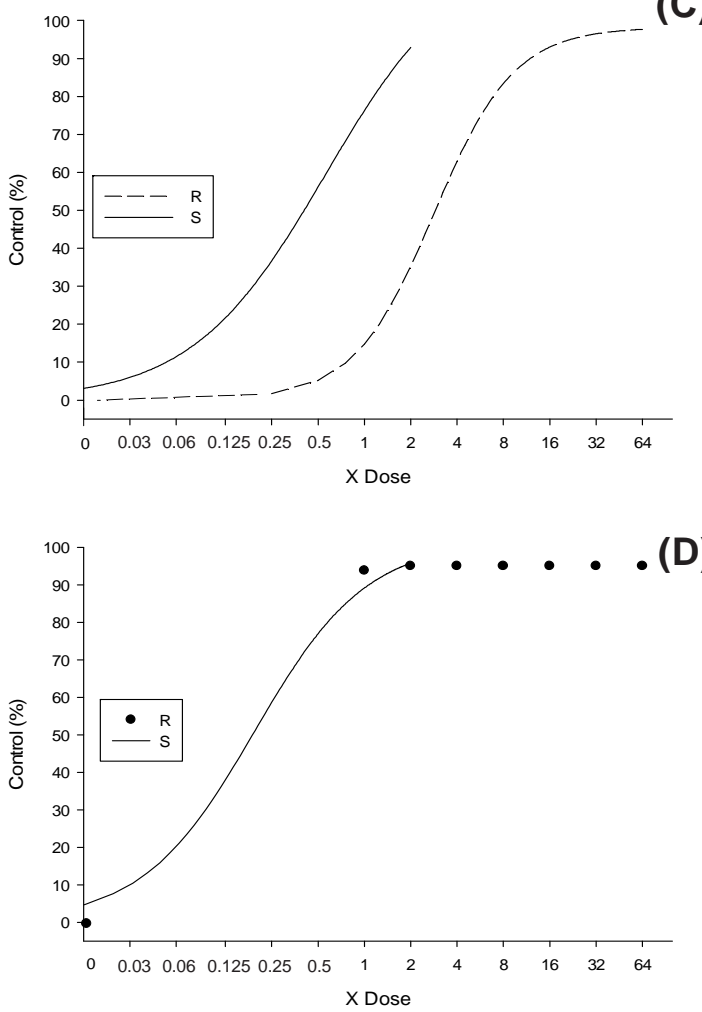

28 DAT
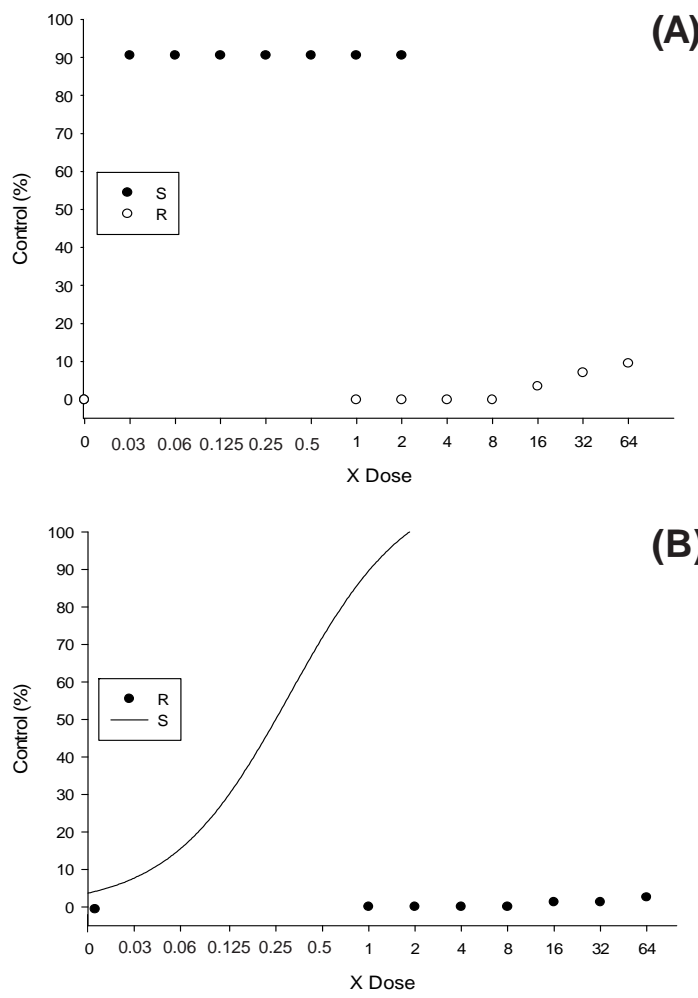

(C)
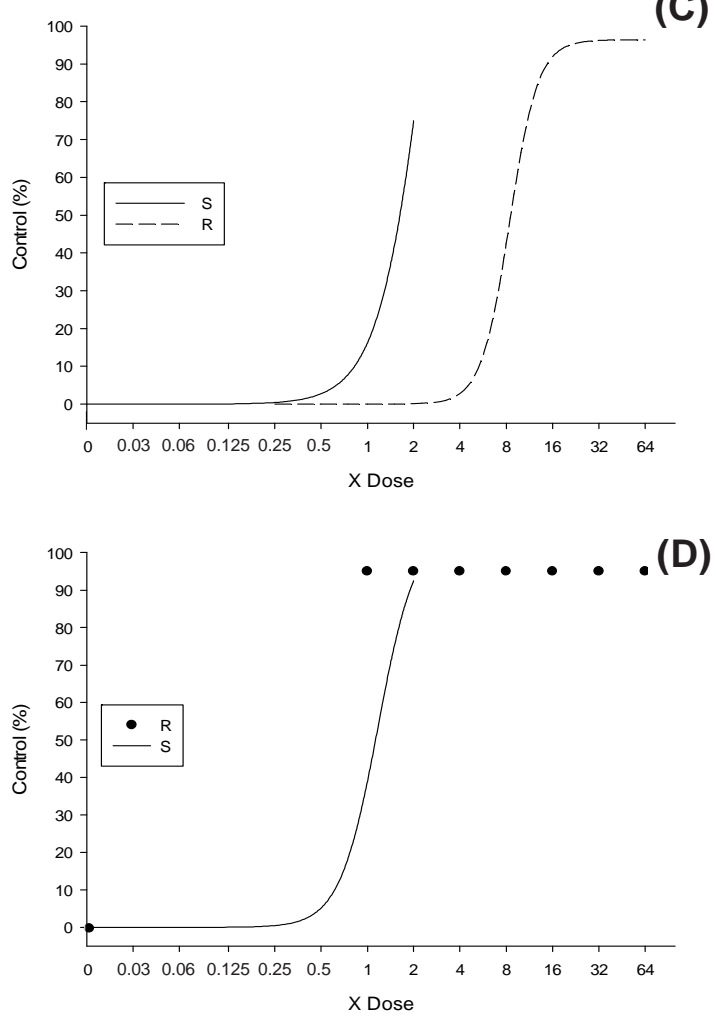

Figure 1 - Control of susceptible (S) and resistant (R) S. montevidensis biotypes in percentage subjected to rates of herbicides penoxsulam (A), (imazethapyr+imazapic) (B), bentazon (C) and saflufenacil (D), at 14 and 28 DAT. 
Table 1 - Sigmoidal regression equations of the logistic type to control S. montevidensis biotypes evaluated at 14 and 28 DAT, with the respective values of the coefficient of determination $\left(\mathrm{R}^{2}\right)$, of $\mathrm{C}_{50}(\mathrm{x}$ dose), confidence intervals $(\mathrm{CI})$, and resistance factor $(\mathrm{RF})$ in response to herbicide rates

\begin{tabular}{|l|c|c|c|c|c|c|}
\hline \multirow{2}{*}{ Herbicide } & \multirow{2}{*}{ Biotype } & Equation & \multirow{2}{*}{$\mathrm{R}^{2}$} & \multicolumn{3}{c|}{$\mathrm{C}_{50^{2 /}}$} \\
\cline { 3 - 7 } & & & & $\mathrm{x}$ dose & $\mathrm{CI}^{3 /}$ & $\mathrm{RF}^{4 /}$ \\
\hline & & & & & & \\
\hline Imazethapyr + imazapic & $\mathrm{S}^{\underline{1} /}$ & $\mathrm{Y}=99.82 /\left[1+(\mathrm{x} / 0.13)^{-1.21}\right]$ & 0.99 & 0.13 & $0.12-0.14$ & - \\
\hline Bentazon & $\mathrm{S}$ & $\mathrm{Y}=118.51 /\left[1+(\mathrm{x} / 0.55)^{-1.00}\right]$ & 0.98 & 0.40 & $0.17-0.63$ & 7.25 \\
\hline Bentazon & $\mathrm{R}$ & $\mathrm{Y}=98.20 /\left[1+(\mathrm{x} / 2.83)^{-1.66}\right]$ & 0.98 & 2.90 & $2.63-3.16$ & - \\
\hline Saflufenacil & $\mathrm{S}$ & $\mathrm{Y}=101.67 /\left[1+(\mathrm{x} / 0.19)^{-1.19}\right]$ & 0.99 & 0.18 & $0.16-0.21$ & - \\
\hline & & $28 \mathrm{DAT}$ & & & & - \\
\hline Imazethapyr + imazapic & $\mathrm{S}$ & $\mathrm{Y}=113.21 /\left[1+(\mathrm{x} / 0.30)^{-1.12}\right]$ & 0.95 & 0.25 & $0.10-0.39$ & - \\
\hline Bentazon & $\mathrm{S}$ & $\mathrm{Y}=250.15 /\left[1+(\mathrm{x} / 2.76)^{-2.62}\right]$ & 0.99 & 1.62 & $0.87-2.37$ & \multirow{2}{*}{5.29} \\
\hline Bentazon & $\mathrm{R}$ & $\mathrm{Y}=96.39 /\left[1+(\mathrm{x} / 8.42)^{-4.70}\right]$ & 0.99 & 8.57 & $8.33-8.80$ & \\
\hline Saflufenacil & $\mathrm{S}$ & $\mathrm{Y}=106.66 /\left[1+(\mathrm{x} / 1.17)^{-3.50}\right]$ & 0.99 & 1.13 & $1.09-1.16$ & - \\
\hline
\end{tabular}

1/ $\mathrm{S}=$ susceptible to herbicides; $\mathrm{R}=$ resistant to ALS and PSII inhibiting herbicides. ${ }^{2 /} \mathrm{C}_{50}=$ dose required to control $50 \%$ of the population. ${ }^{3 /} \mathrm{CI}=$ average confidence interval at $95 \%$ of parameters error probability. ${ }^{4 /} \mathrm{RF}=$ calculation performed by the $\mathrm{C}_{50}$ values of susceptible and resistant biotypes.
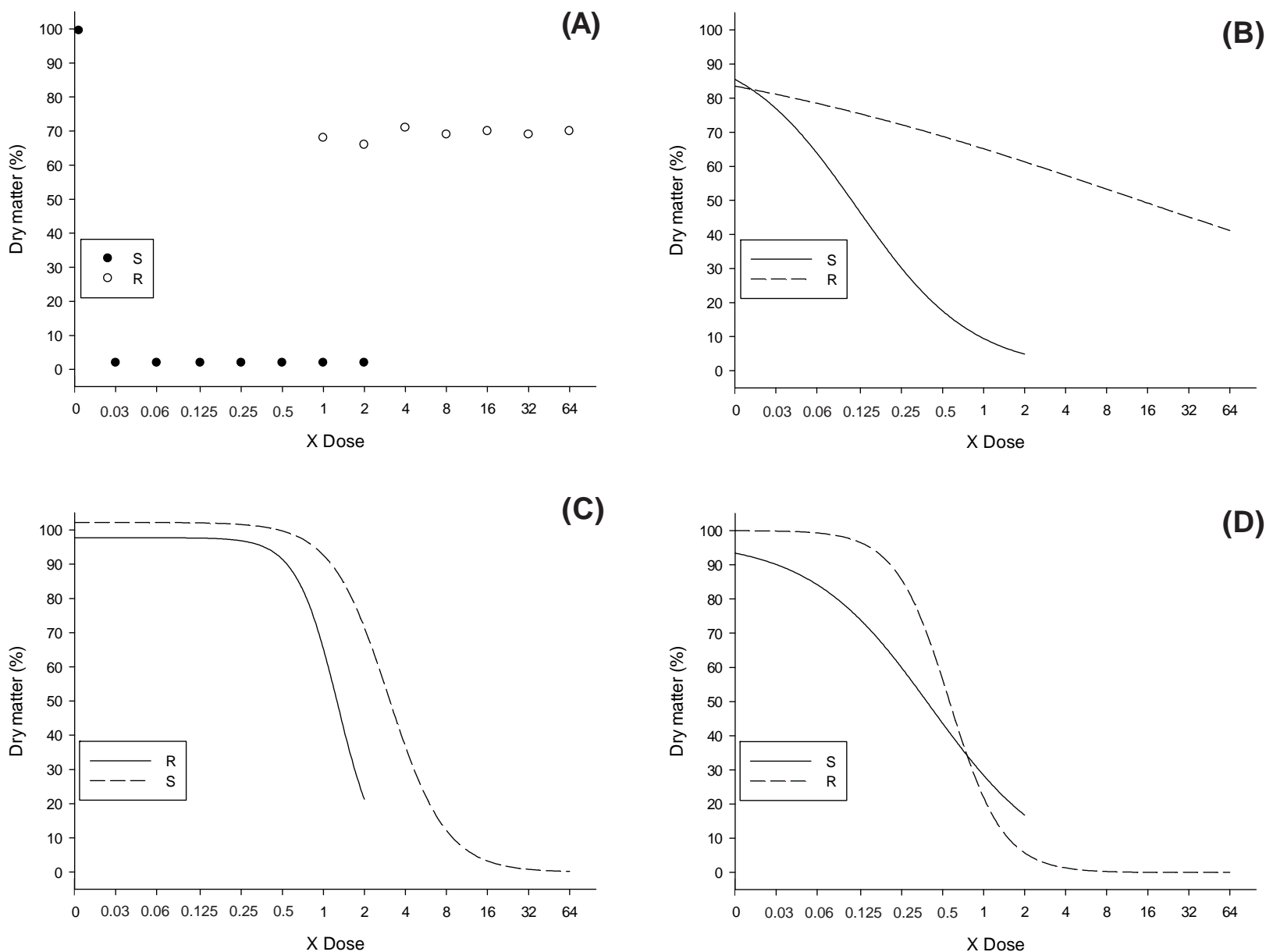

Figure 2 - Shoot dry matter of S. montevidensis biotypes in percentage in response to application of herbicides penoxsulam (A), (imazethapyr+imazapic) (B), bentazon (C) and saflufenacil (D), at 28 DAT. 
Table 2 - Sigmoidal regression equations of logistic type for dry matter of S. montevidensis biotypes assessed at 28 DAT, with respective values of the coefficient of determination $\left(\mathrm{R}^{2}\right)$ of $\mathrm{DM}_{50}$ (x dose), confidence intervals (CI), and resistance factor (RF) in response to the application of herbicide rates for weed control in irrigated rice

\begin{tabular}{|c|c|c|c|c|c|c|}
\hline \multirow{2}{*}{ Herbicide } & \multirow{2}{*}{ Biotype } & \multirow{2}{*}{ Equation } & \multirow{2}{*}{$\mathrm{R}^{2}$} & \multicolumn{3}{|c|}{$\mathrm{DM}_{50}{ }^{2 /}$} \\
\hline & & & & $\mathrm{x}$ dose & $\mathrm{CI}^{3 /}$ & $\mathrm{RF}^{4 /}$ \\
\hline \multirow{2}{*}{ Imazethapyr + imazapic } & $S^{1^{\prime \prime}}$ & $\mathrm{Y}=95.75 /\left[1+(\mathrm{x} / 0.11)^{1.03}\right]$ & 0.93 & 0.10 & $0.06-0.14$ & \multirow{2}{*}{138} \\
\hline & $\mathrm{R}$ & $\mathrm{Y}=100.19 /\left[1+(\mathrm{x} / 13.79)^{0.23}\right]$ & 0.98 & 13.80 & $9.28-18.3$ & \\
\hline \multirow{2}{*}{ Bentazon } & $\mathrm{S}$ & $\mathrm{Y}=97.73 /\left[1+(\mathrm{x} / 1.27)^{2.84}\right]$ & 0.97 & 1.25 & $1.15-1.35$ & \multirow{2}{*}{2.46} \\
\hline & $\mathrm{R}$ & $\mathrm{Y}=102.19 /\left[1+(\mathrm{x} / 3.02)^{2.05}\right]$ & 0.99 & 3.08 & $2.90-3.25$ & \\
\hline \multirow{2}{*}{ Saflufenacil } & $\mathrm{S}$ & $\mathrm{Y}=97.05 /\left[1+(\mathrm{x} / 0.40)^{0.98}\right]$ & 0.93 & 0.38 & $0.25-0.50$ & \multirow{2}{*}{1.47} \\
\hline & $\mathrm{R}$ & $\mathrm{Y}=100.00 /\left[1+(\mathrm{x} / 0.56)^{2.20}\right]$ & 0.99 & 0.56 & $0.48-0.63$ & \\
\hline
\end{tabular}

$\underline{1}^{\prime} \mathrm{S}=$ susceptible to herbicides; $\mathrm{R}=$ resistant to ALS and PSII inhibiting herbicides. ${ }^{2 /} \mathrm{DM}_{50}=$ dose required to reduce $50 \%$ of dry matter. ${ }^{3} / \mathrm{CI}=$ confidence interval at $95 \%$ of parameters error probability. ${ }^{4 /} \mathrm{RF}=$ calculation performed by the $\mathrm{DM}_{50}$ values of susceptible and resistant biotypes.

inhibiting herbicides demonstrates the high level of resistance of SAGMO 32 biotype.

In a study conducted in the field, testing SAGMO control with different herbicides, Eberhardt et al. (2013) observed insignificant control of SAGMO 32 biotype. In the same work, in the best situation, penoxsulam, bispyribac-sodium and pyrazosulfuron-ethyl used in their respective recommended rates, controlled respectively, 13,18 and $3 \%$ of the SAGMO plants; when the rate was quadrupled, the level of control did not increased.

In another study carried out under controlled conditions, Eberhardt et al. (2013) observed high survival (> 80\%) of SAGMO 32 plants when sprayed with the recommended rates of penoxsulam, pyrazosulfuron-ethyl and (imazethapyr+imazapic). The application of eight times the recommended rate for those herbicides resulted in 83, 96 and $71 \%$, respectively. In the same study, the authors also reported that applying half of the recommended rate of penoxsulam, pyrazosulfuron-ethyl and (imazethapyr+ imazapic) in SAGMO 35 biotype, plants control was complete, showing the high susceptibility to these herbicides. This behavior was similar to the results obtained in this study, where the recommended rate of the herbicides penoxsulam and (imazethapyr+imazapic) controlled almost entirely SAGMO 35 biotype. According to Concenço et al. (2007), differences occur between resistant and susceptible S. montevidensis biotypes as to the preferred site of herbicides absorption. Another experiment conducted by Eberhardt et al. (2013) to evaluate the control of SAGMO 32 with herbicide bentazon resulted that the use of $960 \mathrm{~g}$ a.i. ha ${ }^{-1}$ controlled only $18 \%$ of the SAGMO population. When applying four times the recommended rate of bentazon, the control was $78 \%$. When using the rate of $1,920 \mathrm{~g}$ a.i. $\mathrm{ha}^{-1}$, the control was equally very low $(20 \%)$, showing this population's high degree of resistance to this herbicide. These results corroborate with those of the present study, where the application of $960 \mathrm{~g}$ a.i. ha ${ }^{-1}$ of bentazon controlled only $10 \%$ of the resistant population. When the rate of bentazon was increased up to $4 \mathrm{x}$, the control was $70 \%$. As for the ALS inhibiting herbicides, the biotype showed low level of control with bentazon, demonstrating the high level of resistance to it.

For SAGMO 35 biotype, the recommended rate of bentazon (960 g a.i. ha ${ }^{-1}$ ) controlled more than $85 \%$, and the use of half rate controlled approximately 55\% of the plants. These results are similar to those reported by Eberhardt et al. (2013), who observed control of all SAGMO 35 plants with rates equal or greater than $960 \mathrm{~g}$ a.i. ha ${ }^{-1}$; even with only $50 \%$ of the rate the control was around $50 \%$.

In this study, the application of $100 \mathrm{~g}$ a.i. ha ${ }^{-1}$ of saflufenacil provided SAGMO control higher than $90 \%$ for both biotypes: SAGMO 32 and SAGMO 35. It should be noted that the variation of saflufenacil rates of 70-147 g a.i. ha ${ }^{-1}$ did not affect the level of 
control (Eberhardt et al., 2013). Based on the results obtained, saflufenacil can be used for controlling $S$. montevidensis multiple resistant to ALS and PSII in postemergence in irrigated rice. However, other cultivation practices should be associated with herbicide application, including soil tillage, with preparation and sowing in dry soil, always avoiding the evolution of the populations' resistance.

Based on the results of this study it is possible to conclude that SAGMO 32 biotype presents multiple resistance to ALS [penoxsulam, (imazethapyr+imazapic)] and photosystem II (bentazon) inhibiting herbicides. The high values of SAGMO 32 resistance factor for penoxsulam, (imazethapyr+imazapic) and bentazon prevent the use of these herbicides to control resistance $S$. montevidensis populations. Herbicide saflufenacil presents satisfactory control of SAGMO 32 biotype resistant to ALS and PSII inhibiting herbicides.

\section{ACKNOWLEDGMENT}

To CNPq [Conselho Nacional de Desenvolvimento Científico e Tecnológico (National Council of Technological and Scientific Development)] - process 562451/ 2010-2, for the Productivity in Research (PQ) scholarship to the third author, and to Fapesc [Fundação de Amparo à Pesquisa e Inovação do Estado de Santa Catarina (Foundation for Support to Research and Innovation of the state of Santa Catarina)] - award term 6946/ 2011-9, for the financial support for the research implementation.

\section{LITERATURE CITED}

CASSOL, B.; AGOSTINETTO, D.; MARIATH, J. E. A. Análise morfológica de Sagittaria montevidensis desenvolvida em diferentes condições de inundação. Planta Daninha, v. 26, n. 3, p. 487-496, 2008.

CHRISTOFFOLETI, P. J. Bioensaio para determinação da resistência de plantas daninhas aos herbicidas inibidores da enzima ALS. Bragantia, v. 60, n. 3, p. 261-265, 2001.

CHRISTOFFOLETI, P. J. Curvas de dose-resposta de biótipos resistente e suscetível de Bidens pilosa L. aos herbicidas inibidores da ALS. Sci. Agric., v. 59, n. 3, p. 513-519, 2002.

Planta Daninha, Viçosa-MG, v. 33, n. 4, p. 779-786, 2015
CONCENÇO, G. et al. Aspectos da resistência de Sagittaria montevidensis ao herbicida pirazosulfuron-ethyl inibidor da ALS. Planta Daninha, v. 25, n. 1, p. 187-194, 2007.

EBERHARDT, D. S.; NOLDIN, J. A. Multiple HerbicideResistant Sagittaria montevidensis population in Santa Catarina State (Brazil) Rice Fields. WSSAAbstracts... 2011. Disponível em: <http://www.weedscience.org/Case/ Reference.asp?ReferenceID=1166>. Acesso em: 10 jan. 2015.

EBERHARDT, D. S. et al. Sagittaria montevidensis com resistência múltipla a herbicidas em lavouras de arroz irrigado de Santa Catarina. In: CONGRESSO BRASILEIRO DE ARROZ IRRIGADO, 8., 2013, Santa Maria, RS. Anais... Santa Maria: UFSM/Sosbai, 2013. p. 315-318.

EMPRESA BRASILEIRA DE PESQUISA AGROPECUÁRIA - EMBRAPA. Centro Nacional de Pesquisa de Solos. Sistema brasileiro de classificação de solos. 2.ed. Rio de Janeiro: 2006. 306 p.

MEROTTO JR, A. et al. Isolamento do gene ALS e investigação do mecanismo de resistência a herbicidas em Sagittaria montevidensis. Ci. Rural, v. 40, n. 11, p. 2381-2384, 2010.

POWLES, S. B.; YU, Q. Evolution in Action: Plants resistant to herbicides. Ann. Rev. Plant Biol., v. 61, n. 7, p. 317-347, 2010.

PRIGOL, A. et al. Avaliação de biótipos de leiteiro com suspeita de resistência a herbicidas inibidores da ALS e Protox provenientes de Rondônia. R. Bras. Herbic., v. 13, n.3, p. 216-224, 2014.

SHRESTHA, A. et al. Growth, phenology, and intraspecific competition between glyphosate-resistant and glyphosatesusceptible horseweed (Conyza canadensis) in the San Joaquin Valley of California. Weed Sci., v. 58, n. 2, p. 147-153, 2010.

SOCIEDADE BRASILEIRA DA CIÊNCIA DAS PLANTAS DANINHAS - SBCPD. Procedimentos para a instalação, avaliação e análise de experimentos com herbicidas. Londrina: 1995. 42 p.

SOCIEDADE SUL-BRASILEIRA DE ARROZ IRRIGADO - SOSBAI. Arroz irrigado: recomendações técnicas da pesquisa para o Sul do Brasil. Pelotas: UFSM/Sosbai, Santa Maria, RS. 2014. 189 p.

STREIBIG, J. C. Herbicide bioassay. Weed Res., v. 28, n. 1, p. 479-484, 1988. 